Alteration of $\mathrm{Na}_{\mathrm{V}} 1.5$ mechanosensitivity by capsaicin

Page 1 Cowan et al.

1

\title{
Capsaicin alters human Nav1.5 mechanosensitivity
}

Luke M. Cowan ${ }^{1,2}$, Peter R. Strege ${ }^{1,2}$, Radda Rusinova ${ }^{3}$, Olaf S. Andersen ${ }^{3}$, Arthur Beyder ${ }^{1,2 *}$, Gianrico Farrugia ${ }^{1,2 *}$

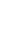

${ }^{1}$ Enteric Neuroscience Program (ENSP), Division of Gastroenterology and Hepatology, ${ }^{2}$ Department of Physiology and Biomedical Engineering, Mayo Clinic, Rochester, MN ${ }^{3}$ Department of Physiology and Biophysics, Weill Cornell Medical College, New York, NY

(1)

12

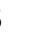

14

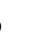

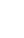

Running Head: Alteration of Nav1.5 mechanosensitivity by capsaicin

8

*Co-Corresponding authors:

Arthur Beyder, M.D. Ph.D. \& Gianrico Farrugia

Mayo Clinic

200 First Street SW

Rochester, Minnesota 55905

Phone: 507-284-4695. Fax: 507-284-0266

Email: beyder.arthur@mayo.edu \& farrugia.gianrico@mayo.edu 
Alteration of $\mathrm{Na}_{\mathrm{v}} 1.5$ mechanosensitivity by capsaicin

Page 2 Cowan et al.

\section{AUTHOR CONTRIBUTIONS}

29 Luke M. Cowan: conceived and designed research, performed experiments, analyzed data,

30 interpreted results of experiments, prepared figures, drafted manuscript, edited and revised

31 manuscript, approved final version of manuscript

32 Peter R. Strege: conceived and designed research, performed experiments, analyzed data,

33 interpreted results of experiments, prepared figures, edited and revised manuscript, approved final

34 version of manuscript

35 Radda Rusinova: conceived and designed research, analyzed data, interpreted results of experiments, edited and revised manuscript, approved final version of manuscript

37 Olaf S. Andersen: conceived and designed research, analyzed data, interpreted results of

38 experiments, edited and revised manuscript, approved final version of manuscript

39 Gianrico Farrugia: conceived and designed research, edited and revised manuscript, approved final

40 version of manuscript

41 Arthur Beyder: conceived and designed research, analyzed data, interpreted results of experiments,

42 edited and revised manuscript, approved final version of manuscript 
Alteration of $\mathrm{Na}_{\mathrm{V}} 1.5$ mechanosensitivity by capsaicin

Page 3 Cowan et al.

\section{ABSTRACT}

$S C N 5 A$-encoded Nav1.5 is a voltage-gated $\mathrm{Na}^{+}$channel expressed in cardiac myocytes and human gastrointestinal (GI) smooth muscle cells (SMCs). Nav1.5 contributes to electrical

47 excitability in the heart and slow waves in the gut. Nav1.5 is also mechanosensitive, and mechanical force modulates several modes of Nav1.5's voltage-dependent function. Nav1.5 mutations in patients with cardiac arrhythmias and gastrointestinal diseases lead to abnormal mechano- and voltage-sensitivity. Membrane permeable amphipathic drugs that target Nav1.5 in

51 the heart and GI tract alter Nav1.5 mechanosensitivity (MS), suggesting that amphipaths may be

52 a viable therapeutic option for modulating Nav1.5 function. We therefore searched for membranepermeable amphipathic agents that would modulate Nav1.5 MS with minimal effect on Nav1.5

54 voltage-gating intact to more selectively target mechanosensitivity. We used two methods to assess Nav1.5 MS: (1) membrane suction in cell-attached macroscopic patches and (2) fluid shear stress on whole cells. We tested the effect of capsaicin on Nav1.5 MS by examining macropatch and

57 whole-cell $\mathrm{Na}^{+}$current parameters with and without force. The pressure- and shear-mediated peak current increase and acceleration were effectively abolished by capsaicin. Capsaicin abolished the

59 mechanosensitive shifts in the voltage-dependence of activation (shear) and inactivation (pressure and shear). Exploring the recovery from inactivation and use-dependent entry into inactivation, we

61 found divergent stimulus-dependent effects that could potentiate or mitigate the effect of capsaicin,

62 suggesting that mechanical stimuli may differentially modulate Nav1.5 MS. We conclude that 63 selective modulation of MS makes capsaicin is a novel modulator of Nav1.5 MS and a promising therapeutic candidate. 
bioRxiv preprint doi: https://doi.org/10.1101/2021.07.13.452086; this version posted July 14, 2021. The copyright holder for this preprint (which was not certified by peer review) is the author/funder, who has granted bioRxiv a license to display the preprint in perpetuity. It is made available under aCC-BY-NC-ND 4.0 International license.

Alteration of $\mathrm{Na}_{\mathrm{v}} 1.5$ mechanosensitivity by capsaicin

Page 4 Cowan et al.

65 Keywords: amphipathic, arrhythmia, capsaicin, electrophysiology, functional gastrointestinal

66 disorder, ion channel, irritable bowel syndrome, mechanosensitivity, mechanotransduction,

67 voltage-gated sodium channel type 5

68 
Alteration of $\mathrm{Na}_{\mathrm{v}} 1.5$ mechanosensitivity by capsaicin

Page 5

Cowan et al.

\section{INTRODUCTION}

The SCN5A-encoded voltage-gated sodium channel Nav1.5 is mechanosensitive;

72 relevant given that Nav1.5 is expressed in mechanically active tissues like the heart and gastrointestinal tract, where it contributes to electrical excitability in cardiac myocytes (CMs) and

74 slow waves in smooth muscle cells (SMCs), respectively. ${ }^{1}$ At the cellular level, mechanosensitive channels like Nav1.5 detect mechanical stimuli through lipid bilayer tension and/or cytoskeletal deformation. ${ }^{2,3}$ In patch-clamp studies, mechanical stimuli in the form of membrane stretch and

77 fluid shear stress modulate Nav1.5's voltage-dependent function by increasing whole-cell conductance, shifting voltage-dependence to hyperpolarized potentials, and accelerating its

79 activation and inactivation kinetics. Therefore, in the context of cardiac and intestinal smooth muscle tissues, Nav1.5 mechanosensitivity (MS) has important implications. ${ }^{1}$ voltage-gating abnormalities, some associated with abnormal responses to mechanical stimuli. ${ }^{7-10}$

84 Impaired stretch modulation in Nav1.5, for example, occurs in some mutations that also cause 85 LQT3-type cardiac arrhythmias, ${ }^{8,11}$ and some mutations that lead to altered Nav1.5 MS are found in patients with IBS. ${ }^{10,12}$

Because of their involvement in many diseases, ion channels are prime targets for

88 pharmacological treatment. ${ }^{13}$ Drugs for cardiac diseases may modulate the behavior of sodium

89 channels like Nav1.5 and influence mechanosensitivity. ${ }^{13-15}$ Yet, how membrane-permeable 90 amphipathic drugs alter the mechanosensitivity of voltage-gated channels like Nav1.5, or whether they do so by a mechanism separate from $\mathrm{Na}^{+}$current inhibition, remain critical unanswered 
bioRxiv preprint doi: https://doi.org/10.1101/2021.07.13.452086; this version posted July 14, 2021. The copyright holder for this preprint (which

was not certified by peer review) is the author/funder, who has granted bioRxiv a license to display the preprint in perpetuity. It is made available under ACC-BY-NC-ND 4.0 International license.

Alteration of $\mathrm{Na}_{\mathrm{v}} 1.5$ mechanosensitivity by capsaicin

Page 6 Cowan et al.

92 questions. ${ }^{13-15}$ For example, the membrane-permeable, amphipathic local anesthetic lidocaine

93 inhibits peak current while inhibiting Nav1.5 mechanosensitivity at lower concentrations. ${ }^{13,14}$

94 Suggesting separate mechanisms for current inhibition and altered mechanosensation by 95 amphipaths, the anesthetic binding site mutation $\mathrm{F} 1760 \mathrm{~A}^{13}$ eliminates the voltage-dependent

96 inhibition by lidocaine without altering lidocaine's effect on mechanosensitivity. The membrane-

97 impermeant lidocaine analog, QX-314, in contrast had no effect on mechanosensitivity.

We therefore searched for membrane-permeable amphipathic agents with minimal effects

99 on Nav1.5 voltage-gating for their impact on Nav1.5 mechanosensitivity. Among the candidates,

100 capsaicin shows promise, and we characterized its ability to selectively modulate Nav1.5

101 mechanosensitivity. 
Alteration of $\mathrm{Na}_{\vee} 1.5$ mechanosensitivity by capsaicin

Page 7

Cowan et al.

\section{METHODS}

$\underline{\text { Heterologous expression and cell culture }}$

Wild-type SCN5A (Q1077del Nav1.5) ${ }^{16}$ was co-transfected with pEGFP-C1 into HEK-293

cells with Lipofectamine 3000 reagent (Thermo Fisher Scientific, Massachusetts, USA).

107

108

109

110

111

112

113

114

115

116

117

118

119

120

121

122

123

124

125

\section{Electrophysiology}

Pipette fabrication. For whole-cell experiments, electrodes were pulled on a P-97 puller (Sutter Instruments, CA) from KG12 glass to a resistance of 2-5 M $\Omega$. For cell-attached patch experiments, electrodes were pulled from 8250 glass (King Precision Glass, California, USA) then fire-polished to wide-bore, bullet-shaped tips with a final resistance of 1-2 M 2 . Electrodes were coated with R6101 elastomer (Dow Corning, MI) then cured by a heat gun to reduce capacitive transients.

Data acquisition. Whole-cell and cell-attached patch data from HEK-293 cells were recorded at $20 \mathrm{kHz}$ with an Axopatch 200B patch-clamp amplifier, Digidata 1550, and pClamp11 software (Molecular Devices, CA).

Cell-attached patch. Solutions. The pipette solution contained (in mM): $150 \mathrm{Na}^{+}, 160 \mathrm{Cl}^{-}$, $5 \mathrm{~K}^{+}, 2.5 \mathrm{Ca}^{+}, 10 \mathrm{HEPES}$, and 5.5 glucose with an osmolality of $305 \mathrm{mmol} / \mathrm{kg}$ and $\mathrm{pH}$ of 7.35 . $\mathrm{GdCl}_{3}(10 \mu \mathrm{M})$ was included in the pipette solution to inhibit endogenous stretch-activated channels. The bath solution contained (in $\mathrm{mM}$ ): $15 \mathrm{Na}^{+}, 140 \mathrm{Cs}^{+}, 160 \mathrm{Cl}^{-}, 2.5 \mathrm{Ca}^{2+}, 5 \mathrm{~K}^{+}, 10$ HEPES, and 5.5 glucose with an osmolality of $305 \mathrm{mmol} / \mathrm{kg}$ and $\mathrm{pH}$ of 7.35 . Where applicable, capsaicin was diluted 1000-fold in bath solution from a $20 \mathrm{mM}$ ethanol stock then added to the recording chamber. Seal pressures were digitally controlled and monitored by High-Speed Pressure Clamp (HSPC-2, ALA Scientific, NY). Suction $\leq 10 \mathrm{mmHg}$ was applied to establish gigaseals. Episodic protocol and mechanical stimulation by pressure. $\mathrm{Na}^{+}$currents in macroscopic 
Alteration of $\mathrm{Na}_{\mathrm{v}} 1.5$ mechanosensitivity by capsaicin

Page 8

Cowan et al.

126 patches were elicited by an identical pair of voltage ladders with 31-ms pressure steps up to -50

$127 \mathrm{mmHg}$ encompassing the second voltage ladder. Patches were held at $+100 \mathrm{mV}$, stepped briefly

128 for $10 \mathrm{~ms}$ to $+190 \mathrm{mV}$ to close Nav channels, then stepped through a 10-step voltage ladder from

$129+100$ to $0 \mathrm{mV}$ in $21-\mathrm{ms}$ long, $10-\mathrm{mV}$ increments with a total sweep duration (equivalent to the

interpulse interval) of $280 \mathrm{~ms}$. Recordings were an average of 5 runs. Capsaicin $(20 \mu \mathrm{M})$ was

added to the chamber 5 min before testing the effects of the drug. Recovery from inactivation: To

test the effect of pressure on the recovery of Nav1.5 from inactivation, cells were held at $120 \mathrm{mV}$

and stepped to (1) $20 \mathrm{mV}$ for $30 \mathrm{~ms}$, next to (2) $120 \mathrm{mV}$ for a variable duration to recover, then to

(2) $20 \mathrm{mV}$ for $30 \mathrm{~ms}$. The time between the beginning of each sweep was $5 \mathrm{~s}$. The length of the

recovery time in stage (2) was varied between 1 and $300 \mathrm{~ms}$, with half-log unit increments. The

pressure step per sweep was $400 \mathrm{~ms}$ regardless of recovery time. Use-dependent inactivation: To

$120 \mathrm{mV}$ and stepped 20 times to $20 \mathrm{mV}$, and the frequency between steps was 33.33 to $3.33 \mathrm{~Hz}$.

The pressure step per sweep was $30 \mathrm{~ms}$.

Whole-cell voltage clamp. Solutions. The intracellular solution contained (in mM): 145 measure peak $\mathrm{Na}^{+}$current density, cells transfected with Nav1.5 were held at $-120 \mathrm{mV}$ then pulsed through a 2-stage, 19-step voltage ladder (1) from -110 to $-30 \mathrm{mV}$ in $5 \mathrm{mV}$ intervals for $2.9 \mathrm{~s}$ each 
Alteration of $\mathrm{Na}_{\mathrm{V}} 1.5$ mechanosensitivity by capsaicin

Page 9 Cowan et al.

peak inward current without shear. Recovery from inactivation: Recovery from inactivation was measured by holding cells at $-130 \mathrm{mV}$ and the pulsed through a 3-stage, 10-step protocol to (1) -30 $\mathrm{mV}$ for $100 \mathrm{~ms}$, next to (2) $-130 \mathrm{mV}$ for a variable duration to recover, then to (2) $-30 \mathrm{mV}$ for 100 ms. The time between sweep starts was $2.5 \mathrm{~s}$. The length of the recovery time in stage (2) of sweep $n$ was $4 * 2^{n}$ ms for a total of $n=10$ sweeps. Use-dependent inactivation: To measure the onset of Nav1.5 inactivation, cells were held at $-130 \mathrm{mV}$ and stepped 10 times to $-40 \mathrm{mV}$, in which the frequency of steps recorded ranged between 0.3 and $50 \mathrm{~Hz}$. Mechanical stimulation by shear stress. When testing the effect of shear stress, the extracellular (bath) solution was perfused by gravity drip (at $10 \mathrm{~mL} / \mathrm{min}$ ) for the duration of the voltage protocol.

\section{Data Analysis}

The maximum peak $\mathrm{Na}^{+}$current and voltage dependence of activation were determined by fitting the Nav1.5 current-voltage (I-V) plots with $I_{V}=G_{M A X} *\left(V-E_{R E V}\right) /\left(1+e^{(V-V 1 / 2 A) / s l o p e}\right)$, where $G_{M A X}$ is the maximum $\mathrm{Na}^{+}$conductance in whole cells (IMAX is the maximum $\mathrm{Na}^{+}$current in patches), and $V_{1 / 2 A}$ is the voltage of half-activation. Activation kinetics were determined by fitting currents with a two-term weighted exponential function: $I(t)=A_{1} e^{(-t / \tau A)}+A_{2} e^{(-t / \tau I)}$, where $\tau_{A}$ and $\tau_{I}$ are the time constants of activation and inactivation, respectively, and $A X$ and $C$ were constants. Steady-state inactivation was obtained by fitting available peak $\mathrm{Na}^{+}$currents with a 3-parameter sigmoid curve: $I_{V}=1 /\left(1+e^{((V-V I / 2 I) / \delta V I)}\right)$, where $V_{I / 2 I}$ is the half-point of steady-state inactivation (availability), and $\delta V_{I}$ the slope. To determine the recovery from inactivation, peak $\mathrm{Na}^{+}$currents were fit with the equation: $I / I_{0}=I /\left(1+t / t_{1 / 2}\right)^{b}$, where $I / I_{0}$ is the ratio of $\mathrm{Na}^{+}$current recovered following inactivation from the control current, $b$ the rate of inactivation recovery, and $t_{1 / 2}$ the time where half of the $\mathrm{Na}^{+}$current has recovered from inactivation. Use-dependent inactivation was estimated by fitting the peak $\mathrm{Na}^{+}$currents of successive pulses with the equation: $I_{10} / I_{1}=I_{f} e^{b /(x+c)}$, 
bioRxiv preprint doi: https://doi.org/10.1101/2021.07.13.452086; this version posted July 14, 2021. The copyright holder for this preprint (which

was not certified by peer review) is the author/funder, who has granted bioRxiv a license to display the preprint in perpetuity. It is made available under aCC-BY-NC-ND 4.0 International license.

Alteration of $\mathrm{Na}_{\mathrm{v}} 1.5$ mechanosensitivity by capsaicin

Page 10

Cowan et al.

172 where $I_{10} / I_{l}$ is the peak $\mathrm{Na}^{+}$current in step 10 normalized to the peak of step 1 , and $I_{f}$ the maximally

173 inactivated peak $\mathrm{Na}^{+}$current at frequency $f$, and $b$ or $c$ is the rate or constant of use-dependent

174 inhibition, respectively. To calculate the half-frequency of use-dependent inactivation, $I_{f}$ was

175 plotted $v s$. pulse frequency $f$ and fit with $I_{f}=(1-a) /\left(1+e^{(f 1 / 2-f) / b}\right)$, where $a$ is limit of use-dependent

176 inhibition, $f_{1 / 2}$ the half frequency of use-dependent inhibition, and $b$ the slope. Data are expressed

177 as the mean \pm standard error of the mean (SEM). Significance was tested using a 2-way ANOVA

178 with Tukey post-test, in which $P<0.05$ when comparing force to rest or capsaicin to drug-free. 
Alteration of $\mathrm{Na}_{\mathrm{V}} 1.5$ mechanosensitivity by capsaicin

Page 11

Cowan et al.

\section{RESULTS}

$\underline{\text { Screen of amphipathic membrane-permeable drugs }}$

We examined select amphipathic agents with high partition coefficients (Table 1) as potential modulators of Nav1.5 voltage dependence. ${ }^{17-20}$ We tested each compound $\left(10^{-9}\right.$ to $10^{-4}$ M) for its ability to inhibit peak voltage-gated $\mathrm{Na}^{+}$currents (Figure 1A-D). Of the agents tested,

Triton X-100 $\left(\log P_{\text {ow }} 4.6, \mathrm{IC}_{50} 5.3 \mu \mathrm{M}\right.$, Figure $\left.1 \mathrm{C}-\mathrm{D}\right)$, was the most potent and capsaicin $\left(\log P_{\mathrm{OW}}\right.$

$\log P_{\text {ow }}$ is not a good predictor of the drug's effect on Nav1.5 voltage-gated function. Because our we chose capsaicin $(20 \mu \mathrm{M})$ for further investigation, as this dose inhibited voltage-dependent $\mathrm{Na}^{+}$ current by $\leq 25 \%$ without mechano stimulus (Figure 1B-D).

$\underline{\text { Capsaicin inhibits increases in peak current and acceleration with mechanical stimuli }}$

To test the effect of capsaicin on Nav1.5 mechanosensitivity, we used two complementary

197 whole-cell configuration with fluid shear stress (Tables 2-3, Figure 2). These complementary techniques allow us to highlight different aspects of the channels' mechanosensitivity due to both techniques' intrinsic strengths and weaknesses. ${ }^{11,21-23}$ The effect of pressure was tested in a pairwise fashion ${ }^{1,11,14}$, with pressure at 0 or $-30 \mathrm{mmHg}$ applied at each voltage step (Figure 2A,C,EH). Whole-cell current responses to shear was tested by perfusion at 0 or $10 \mathrm{~mL} / \mathrm{min}$ (Figure 
Alteration of $\mathrm{Na}_{\mathrm{V}} 1.5$ mechanosensitivity by capsaicin

Page 12

Cowan et al.

203 (Tables 2-3, Figure 2A-H). Suction increased normalized peak currents (IMAx) by 16.6 $\pm 2.4 \%$

$204(P<0.05 ; \mathrm{n}=24$; Figure 2A,C,E), and shear increased the peak current (IPEAK) by $16.0 \pm 3.1 \%$ in

205 whole cells $(0.26 \pm 0.10 \mathrm{nS}$ increase in conductance; $P<0.05,0$ to $10 \mathrm{~mL} / \mathrm{min} ; \mathrm{n}=12$; Figure

206 2B,C,E). Capsaicin decreased IPEAK by $22.1 \pm 3.9 \%(P<0.05,0$ to $20 \mu \mathrm{M}$ capsaicin $)$, and both

207 pressure $(+4.8 \pm 3.0 \%)$ and shear sensitivity $(+3.1 \pm 3.8 \%,+0.08 \pm 0.05 \mathrm{nS})$ were lost $(\mathrm{n}=12-14$,

$208 P>0.05$ to drug with no force).

In the absence of drug, pressure and shear accelerated $\mathrm{Na}^{+}$current activation, decreasing or shear $(-11.0 \pm 5.4 \%$ or $-1.3 \pm 7.0 \%$, respectively; $\mathrm{n}=12-14, P>0.05$ to drug with no force, Figure kinetics of Nav1.5 in both experimental configurations.

217 Capsaicin inhibits mechanically induced hyperpolarizing shifts in the voltage dependence of $\underline{\text { activation and availability }}$

Pressure $^{1,13,14,24}$ and shear ${ }^{3,11,12}$ produce hyperpolarizing shifts in the voltage dependence of Nav1.5 activation and inactivation. Membrane-permeable amphipathic drugs like lidocaine and ranolazine reduce these mechanosensitive shifts in voltage dependence. ${ }^{13}, 14$ Therefore, we

222 explored whether capsaicin could reduce the pressure- or shear-induced shifts in voltage 223 dependence. Like in our previous work without $\operatorname{drug}^{13,14}$, suction $(-30 \mathrm{mmHg})$ produced a leftward 224 shift of $-4.5 \pm 0.6 \mathrm{mV}$, and shear stress induced a smaller but significant shift of $-1.5 \pm 0.6 \mathrm{mV}$ in the 
Alteration of $\mathrm{Na}_{\mathrm{v}} 1.5$ mechanosensitivity by capsaicin

Page 13

Cowan et al.

226 Without force, capsaicin produced a hyperpolarized shift in $\mathrm{V}_{1 / 2 \mathrm{~A}}(-1.6 \pm 0.4 \mathrm{mV} ; P<0.05,0$ to 20

$227 \mu \mathrm{M}$ capsaicin) in whole cells. With force, capsaicin inhibited the shear-induced shift in $\mathrm{V}_{1 / 2 \mathrm{~A}}$

$228(-0.3 \pm 0.1 \mathrm{mV}, P>0.05$ to drug with no shear) but not the pressure-induced shift $(-2.4 \pm 0.6 \mathrm{mV}$,

$229 P<0.05$ to drug with no pressure). Similar to shear-induced shifts in $\mathrm{V}_{1 / 2 \mathrm{~A}}$, pressure or shear shifted

230 the voltage dependence of inactivation or availability $\left(\mathrm{V}_{1 / 2 \mathrm{I}}\right)$ in the absence of capsaicin $(-6.0 \pm 0.9$

$231 \mathrm{mV}$ with pressure or $-2.5 \pm 0.9 \mathrm{mV}$ with shear, $P<0.05$ to no force) (Tables 2-3, Figure $2 \mathrm{D}, \mathrm{H}$ ).

232 Without force, capsaicin produced a hyperpolarizing shift in whole-cell $\mathrm{V}_{1 / 2 \mathrm{I}}$ by $-5.1 \pm 0.7 \mathrm{mV}$, as

233 previously observed ${ }^{25}$. In the presence of capsaicin, however, neither pressure nor shear had a

234 significant effect on $\mathrm{V}_{1 / 2 \mathrm{I}}(-1.4 \pm 1.2$ or $-0.5 \pm 0.6 \mathrm{mV}$ change, respectively, $P>0.05$ to drug with no

235 force), suggesting loss of the MS of Nav1.5 inactivation. Overall, our results show that capsaicin

236 inhibited the mechanosensitive shifts in Nav1.5 gating.

237 Effects of capsaicin and mechanical stimuli on recovery from inactivation

Both capsaicin and pressure delay recovery of Nav1.5 from fast inactivation., ${ }^{1,25}$ Therefore,

we tested whether the presence of capsaicin affected the recovery from fast inactivation (1 to 1000

$\mathrm{ms}$ ) in the absence or presence of mechanical stimuli (Tables 2-3, Figure 3A-B). Without force or

Nav1.5 inactivation recovery $\left(\mathrm{t}_{1 / 2 \mathrm{R}}\right)$ at rest was $13.2 \pm 2.5 \mathrm{~ms}$ in the patch and $18.8 \pm 1.7 \mathrm{~ms}$ in whole-

244 stimulus or configuration described above, here we observed consistent differences between the 
Alteration of $\mathrm{Na}_{\mathrm{V}} 1.5$ mechanosensitivity by capsaicin

Page 14

Cowan et al.

249 increased $\mathrm{t}_{1 / 2 \mathrm{R}}$ by $19.2 \pm 8.2 \mathrm{~ms}(P<0.05$ to drug with no pressure $)$, whereas shear reduced $\mathrm{t}_{1 / 2 \mathrm{R}}$ in

250 whole cells by $9.5 \pm 0.9 \mathrm{~ms}(P<0.05$ to drug with no shear $)$. These data show that shear stress on

whole cells and pressure on patches had opposite effects (shear accelerating, suction slowing). In

both approaches, the recovery from inactivation was delayed by capsaicin, and capsaicin further

delayed recovery in patches but accelerated recovery in whole cells.

254

255

256

257

258

259

260

261

262

263

264

265

266

267

268

269

270

271

Effects of capsaicin and mechanical stimuli on use-dependent inactivation

Capsaicin can stabilize the inactivated state of Nav1.5 through use-dependent inhibition. ${ }^{25}$ The effects of pressure on use-dependent Nav1.5 function have not been fully explored, and we tested whether force can alter use-dependent inactivation of Nav1.5 in the absence or presence of capsaicin (Figure 4A-F). To measure the use-dependent inhibition of Nav1.5 expressed in HEK cells, $\mathrm{Na}^{+}$currents elicited by steps to 0 or $-30 \mathrm{mV}$ in patches or whole cells were sampled at 3-33 $\mathrm{Hz}$ or $0.3-50 \mathrm{~Hz}$, resepectively. Without force or drug, the maximum use-dependent inhibition of Nav1.5 was $80.9 \pm 7.9 \%$ with a half-frequency $\left(f_{1 / 2}\right)$ of $22.3 \pm 2.6 \mathrm{~Hz}$ in patches (Table 2, Figure $4 \mathrm{C}, \mathrm{E}-\mathrm{F}$ ), and $64.6 \pm 2.4 \%$ with a $f_{1 / 2}$ of $26.1 \pm 2.0 \mathrm{~Hz}$ in whole-cells (Table 3, Figure 4D-F). The use dependence did not change with either pressure or shear in the absence of capsaicin $(P>0.05$ to no force, Tables 2-3, Figure 4C-F). In the absence of shear, capsaicin increased the maximum usedependent inhibition of Nav1.5 to $89.0 \pm 1.4 \%$ and decreased $f_{1 / 2}$ to $18.9 \pm 1.0 \mathrm{~Hz}(P<0.05,0$ to 20 $\mu \mathrm{M}$ capsaicin). In the presence of capsaicin, shear produced a modest decrease in the maximum use-dependent inhibition $\left(5.1 \pm 0.9 \% ; P<0.05\right.$ to drug with no shear), and $f_{1 / 2}$ was unaffected, suggesting that shear partially reverses the use-dependent inhibition of Nav1.5 promoted by capsaicin. In patches, capsaicin affected neither the use-dependent inhibition nor $f_{1 / 2}$ at rest $\left(P>0.05,0\right.$ to $20 \mu \mathrm{M}$ capsaicin) but increased the pressure-sensitivity ( $f_{1 / 2}$ decreased by $2.4 \pm 3.3$ $\mathrm{Hz} ; P<0.05$ to drug with no pressure), suggesting that pressure is synergestic with capsaicin to 
bioRxiv preprint doi: https://doi.org/10.1101/2021.07.13.452086; this version posted July 14, 2021. The copyright holder for this preprint (which

was not certified by peer review) is the author/funder, who has granted bioRxiv a license to display the preprint in perpetuity. It is made available under aCC-BY-NC-ND 4.0 International license.

Alteration of $\mathrm{Na}_{\mathrm{v}} 1.5$ mechanosensitivity by capsaicin

Page 15 Cowan et al.

272 decrease the frequency at which Nav1.5 undergoes use dependent inhibition. Together, our results

273 suggest that though capsaicin enhances use-dependent inhibition, its effect on force-dependent

274 changes to Nav1.5 use dependence may be specific to the type of force applied. 
Alteration of $\mathrm{Na}_{\mathrm{V}} 1.5$ mechanosensitivity by capsaicin

Page 16

Cowan et al.

\section{DISCUSSION}

Our study aimed to test the impact of a membrane-permeable amphipathic agent on Nav1.5

278

279

280

281

282

283

284

285

286

287

288

289

290

291

292

293

294

295

296

297 mechanosensitivity. We selected compounds with high partition coefficients and tested the inhibition of Nav1.5 voltage-gating. Capsaicin inhibited Nav1.5 mechanosensitivity comparable to the amphipaths lidocaine $\mathrm{e}^{13,14}$ and ranolazine ${ }^{14}$. Capsaicin consistently inhibited the effects of pressure or shear stress on Nav1.5 in membrane patches or whole cells, respectively, by (1) diminishing the mechanosensitive increases in $\mathrm{Na}^{+}$current, (2) shifts in steady-state voltage dependence, and (3) acceleration of Nav1.5 gating kinetics.

Quantifying mechanosensitive changes in ion channel function can be challenging, and few studies have explored Nav1.5 mechanosensitivity using whole-cell and patch modes in parallel. ${ }^{l,}$ 11,13 To our knowledge, this is the first study to compare the effects of pressure and shear on the mechanosensitive operation of Nav1.5 in the absence nor presence of drug. Most of Nav1.5's mechanosensitive responses and capsaicin's effects on Nav1.5 MS were similar in the two testing modes. Both produced an increase in peak $\mathrm{Na}^{+}$current, a shift in $\mathrm{V}_{1 / 2} \mathrm{~A}$, a shift in $\mathrm{V}_{1 / 2 \mathrm{I}}$, and an acceleration in $\tau_{\mathrm{A}}$. Capsaicin, using either approach, inhibited MS effects on the above biophysical parameters. This is important because mechanical strain leads to faster and greater $\mathrm{Na}^{+}$influx, which increases Nav channel availability and further depolarizes the membrane (closer to the threshold to fire action potentials or elicit autonomous membrane depolarizations). Capsaicin would reduce $\mathrm{Na}^{+}$influx, slow membrane depolarization (or hyperpolarize the membrane) thereby reducing the effect of mechanical forces on Nav channel availability.

Surprisingly, we found opposite responses in the pressure- and shear-sensitivity of Nav1.5 inactivation recovery and use-dependent inactivation. Pressure increased the inactivation recovery time, whereas shear stress decreased it. Addition of capsaicin to patches resulted in a 
Alteration of $\mathrm{Na}_{\mathrm{V}} 1.5$ mechanosensitivity by capsaicin

Cowan et al.

299 further delay of Nav1.5 inactivation recovery in patches under pressure, in contrast to whole

cells, where shear stress accelerated inactivation recovery whether or not capsaicin was present.

Similarly, capsaicin and pressure, when applied together, decreased the frequency of use-

317 Therefore, while both stimuli may be used to study mechanosensitivity of Nav1.5 and other

318 mechanosensitive ion channels, functional consequences may be dependent on channel's

319 functional modes under study. 
Alteration of $\mathrm{Na}_{\mathrm{v}} 1.5$ mechanosensitivity by capsaicin

Page 18

Cowan et al.

322 the pore lumen DIS6 segment, in the analogous position and across from F1760 in the local

323 anesthetic binding site on the DIVS6 segment. ${ }^{25}, 30$ Interestingly, the IR sequence in Nav1.5

324 (L407W-L409C-A410W) would be 9 amino acids downstream from and functionally similar to

325 IR mutant T220A in bacterial homolog NaChBac, which has greater shear-sensitivity than its wild-

326 type. Whether inhibition of mechanosensitivity by capsaicin requires the LXLA sequence in

327 Nav1.5 remains to be seen, yet finding a shared interaction motif suggests that the LA binding

328 region might sensitize Nav1.5 and other mechanosensitive voltage-gated channels ${ }^{31}$ or mechano-

329 gated channels ${ }^{32}$ to amphipathic MS inhibition. Capsaicin had divergent effects on pressure- and

330 shear-sensitivity of Nav1.5 use-dependent inhibition or inactivation recovery, suggesting that

331 specific types of force may differentially modulate Nav1.5 mechanosensitivity.

Another amphiphilic Nav1.5 modulator, ranolazine, inhibits the increase in peak $\mathrm{Na}^{+}$

stress comparable to capsaicin ${ }^{14}$. Ranolazine is an anti-ischemic agent that may cause constipation

as a common side effect ${ }^{33}$; muscle contractility in human colon smooth muscle cells was lost when

ranolazine inhibited Nav1.5 peak current and mechanosensitivity. ${ }^{34}$ The effects of capsaicin,

337 lidocaine ${ }^{13}$, and ranolazine ${ }^{14}$ as mechanosensitivity inhibitors demonstrate that membrane-

338 permeable amphipathic agents may be candidates for modulating Nav1.5 mechanosensitivity and

339 targeting dysfunction in mechanosensitive channelopathies. Amphipathic drugs are widely used in

340 the clinical practice to target ion channels, but are rarely used for mechano-modulation. ${ }^{12,13}$

341 Channelopathies involving mechanosensitive dysfunction are an emerging area of study. 6, 7, 9-11, 35

342 Ion channelopathies in voltage-sensitive mechano-gated Piezo channels ${ }^{36-38}$ and channelopathies

343 affecting Nav1.5 mechanosensitivity have been identified, but both lack treatment options. Hence,

344 drugs that can target and modulate mechanosensitivity carry promise for treating disease. 
bioRxiv preprint doi: https://doi.org/10.1101/2021.07.13.452086; this version posted July 14, 2021. The copyright holder for this preprint (which

was not certified by peer review) is the author/funder, who has granted bioRxiv a license to display the preprint in perpetuity. It is made available under aCC-BY-NC-ND 4.0 International license.

Alteration of $\mathrm{Na}_{\mathrm{v}} 1.5$ mechanosensitivity by capsaicin

Page 19

Cowan et al.

Capsaicin inhibits its canonical target TRPV1 in sensory neurons to improve GI

346 dysfunction in IBS-D patients ${ }^{39}$; however, TRPV1 is not pressure-sensitive up to $-90 \mathrm{mmHg}^{40}$ and

347 does not have high expression in HEK cells ${ }^{29,41}$. Capsaicin has shown promise in targeting pain in

348 IBS. Interestingly, it also has effects on gut motility ${ }^{42-44}$, possibly through it's function on Nav1.5

349 mechanosensivity. Therefore, there may be an exciting possibility of using capsaicin to affect

350 sensory (TRPV1) and motility (SCN5A/Nav1.5) processes by different mechanisms in the GI tract. 
bioRxiv preprint doi: https://doi.org/10.1101/2021.07.13.452086; this version posted July 14, 2021. The copyright holder for this preprint (which

was not certified by peer review) is the author/funder, who has granted bioRxiv a license to display the preprint in perpetuity. It is made available under aCC-BY-NC-ND 4.0 International license.

Alteration of $\mathrm{Na}_{\mathrm{V}} 1.5$ mechanosensitivity by capsaicin

Page 20

Cowan et al.

\section{ACKNOWLEDGEMENTS}

353 We thank Kristy Zodrow for administrative assistance. This work was supported by NIH

354 grants DK052766 (GF), DK106456 (AB), and the National Center for Complementary and

355 Integrative Health AT10875 (AB). 
Alteration of $\mathrm{Na}_{\mathrm{V}} 1.5$ mechanosensitivity by capsaicin

Page 21

Cowan et al.

\section{REFERENCES}

[1] Beyder, A., Rae, J. L., Bernard, C., Strege, P. R., Sachs, F., and Farrugia, G. (2010) Mechanosensitivity of Nav1.5, a voltage-sensitive sodium channel, J Physiol 588, 49694985.

[2] Sukharev, S., and Sachs, F. (2012) Molecular force transduction by ion channels: diversity and unifying principles, J Cell Sci 125, 3075-3083.

[3] Strege, P. R., Holm, A. N., Rich, A., Miller, S. M., Ou, Y., Sarr, M. G., and Farrugia, G. (2003) Cytoskeletal modulation of sodium current in human jejunal circular smooth muscle cells, Am J Physiol Cell Physiol 284, C60-66.

[4] Beyder, A., and Farrugia, G. (2016) Ion channelopathies in functional GI disorders, Am. J. Physiol. Gastrointest. Liver Physiol. 311, G581-G586.

[5] Kass, R. S. (2005) The channelopathies: novel insights into molecular and genetic mechanisms of human disease, The Journal of clinical investigation 115, 1986-1989.

[6] Marban, E. (2002) Cardiac channelopathies, Nature 415, 213-218.

[7] Beyder, A., and Farrugia, G. (2016) Ion channelopathies in functional GI disorders, Am J Physiol Gastrointest Liver Physiol 311, G581-G586.

[8] Banderali, U., Juranka, P. F., Clark, R. B., Giles, W. R., and Morris, C. E. (2010) Impaired stretch modulation in potentially lethal cardiac sodium channel mutants, Channels (Austin) 4, 12-21.

[9] Beyder, A., Mazzone, A., Strege, P. R., Tester, D. J., Saito, Y. A., Bernard, C. E., Enders, F. T., Ek, W. E., Schmidt, P. T., Dlugosz, A., Lindberg, G., Karling, P., Ohlsson, B., Gazouli, M., Nardone, G., Cuomo, R., Usai-Satta, P., Galeazzi, F., Neri, M., Portincasa, P., Bellini, M., Barbara, G., Camilleri, M., Locke, G. R., Talley, N. J., D'Amato, M., Ackerman, M. J., and Farrugia, G. (2014) Loss-of-function of the voltage-gated sodium channel NaV1.5 (channelopathies) in patients with irritable bowel syndrome, Gastroenterology 146, 1659-1668.

[10] Saito, Y. A., Strege, P. R., Tester, D. J., Locke, G. R., 3rd, Talley, N. J., Bernard, C. E., Rae, J. L., Makielski, J. C., Ackerman, M. J., and Farrugia, G. (2009) Sodium channel mutation in irritable bowel syndrome: evidence for an ion channelopathy, Am. J. Physiol. Gastrointest. Liver Physiol. 296, G211-218.

[11] Strege, P. R., Mercado-Perez, A., Mazzone, A., Saito, Y. A., Bernard, C. E., Farrugia, G., and Beyder, A. (2019) SCN5A mutation G615E results in NaV1.5 voltage-gated sodium channels with normal voltage-dependent function yet loss of mechanosensitivity, Channels (Austin) 13, 287-298.

[12] Strege, P. R., Mazzone, A., Bernard, C. E., Neshatian, L., Gibbons, S. J., Saito, Y. A., Tester, D. J., Calvert, M. L., Mayer, E. A., Chang, L., Ackerman, M. J., Beyder, A., and 
Alteration of $\mathrm{Na}_{\mathrm{V}} 1.5$ mechanosensitivity by capsaicin

Page 22

Cowan et al.

Farrugia, G. (2017) Irritable bowel syndrome (IBS) patients have SCN5A channelopathies that lead to decreased NaV1.5 current and mechanosensitivity, $\mathrm{Am} \mathrm{J}$ Physiol Gastrointest Liver Physiol 314, G494-G503.

[13] Beyder, A., Strege, P. R., Bernard, C., and Farrugia, G. (2012) Membrane permeable local anesthetics modulate $\mathrm{Na}(\mathrm{V}) 1.5$ mechanosensitivity, Channels (Austin) 6, 308-316.

[14] Beyder, A., Strege, P. R., Reyes, S., Bernard, C. E., Terzic, A., Makielski, J., Ackerman, M. J., and Farrugia, G. (2012) Ranolazine decreases mechanosensitivity of the voltage-gated sodium ion channel $\mathrm{Na}(\mathrm{v}) 1.5$ : a novel mechanism of drug action, Circulation 125, 26982706.

[15] Kraichely, R. E., Strege, P. R., Sarr, M. G., Kendrick, M. L., and Farrugia, G. (2009) Lysophosphatidyl choline modulates mechanosensitive L-type Ca2+ current in circular smooth muscle cells from human jejunum, Am J Physiol Gastrointest Liver Physiol 296, G833-839.

[16] Makielski, J. C., Ye, B., Valdivia, C. R., Pagel, M. D., Pu, J., Tester, D. J., and Ackerman, M. J. (2003) A ubiquitous splice variant and a common polymorphism affect heterologous expression of recombinant human SCN5A heart sodium channels, Circ. Res. 93, 821-828.

[17] Ho, Y. F., Chou, H. Y., Chu, J. S., and Lee, P. I. (2018) Comedication with interacting drugs predisposes amiodarone users in cardiac and surgical intensive care units to acute liver injury: A retrospective analysis, Medicine (Baltimore) 97, e12301.

[18] LaHann, T. R., DeKrey, L. J., and Tarr, B. D. (1989) Capsaicin analgesia: predictions based on physico-chemical properties, Proc West Pharmacol Soc 32, 201-204.

[19] Avdeef, A., Box, K. J., Comer, J. E., Hibbert, C., and Tam, K. Y. (1998) pH-metric logP 10. Determination of liposomal membrane-water partition coefficients of ionizable drugs, Pharm Res 15, 209-215.

[20] PubChem. (2019) PubChem Compound Summary for CID 5590, Octoxinol, NIH, National Library of Medicine.

[21] Suchyna, T. M., Markin, V. S., and Sachs, F. (2009) Biophysics and structure of the patch and the gigaseal, Biophys $J$ 97, 738-747.

[22] Morris, C. E. (2011) Voltage-gated channel mechanosensitivity: fact or friction?, Front Physiol 2, 25.

[23] Sokabe, M., and Sachs, F. (1990) The structure and dynamics of patch-clamped membranes: a study using differential interference contrast light microscopy, J Cell Biol 111, 599606.

[24] Morris, C. E., and Juranka, P. F. (2007) Nav channel mechanosensitivity: activation and inactivation accelerate reversibly with stretch, Biophys. J. 93, 822-833. 
Alteration of $\mathrm{Na}_{\mathrm{V}} 1.5$ mechanosensitivity by capsaicin

Cowan et al.

[25] Lundbaek, J. A., Birn, P., Tape, S. E., Toombes, G. E., Sogaard, R., Koeppe, R. E., 2nd, Gruner, S. M., Hansen, A. J., and Andersen, O. S. (2005) Capsaicin regulates voltagedependent sodium channels by altering lipid bilayer elasticity, Mol Pharmacol 68, 680689.

[26] Dimitrakopoulos, P. (2012) Analysis of the variation in the determination of the shear modulus of the erythrocyte membrane: Effects of the constitutive law and membrane modeling, Phys Rev E Stat Nonlin Soft Matter Phys 85, 041917.

[27] Lundbaek, J. A., Koeppe, R. E., 2nd, and Andersen, O. S. (2010) Amphiphile regulation of ion channel function by changes in the bilayer spring constant, Proc. Natl. Acad. Sci. U. S. A. $107,15427-15430$.

[28] Lundbaek, J. A., Collingwood, S. A., Ingolfsson, H. I., Kapoor, R., and Andersen, O. S. (2010) Lipid bilayer regulation of membrane protein function: gramicidin channels as molecular force probes, $J R$ Soc Interface 7, 373-395.

[29] Bavi, N., Nakayama, Y., Bavi, O., Cox, C. D., Qin, Q. H., and Martinac, B. (2014) Biophysical implications of lipid bilayer rheometry for mechanosensitive channels, Proc Natl Acad Sci U S A 111, 13864-13869.

[30] Wang, S. Y., Mitchell, J., and Wang, G. K. (2007) Preferential block of inactivationdeficient $\mathrm{Na}+$ currents by capsaicin reveals a non-TRPV1 receptor within the $\mathrm{Na}+$ channel, Pain 127, 73-83.

[31] Lyford, G. L., Strege, P. R., Shepard, A., Ou, Y., Ermilov, L., Miller, S. M., Gibbons, S. J., Rae, J. L., Szurszewski, J. H., and Farrugia, G. (2002) alpha(1C) (Ca(V)1.2) L-type calcium channel mediates mechanosensitive calcium regulation, Am J Physiol Cell Physiol 283, C1001-1008.

[32] Joshi, V., Strege, P. R., Farrugia, G., and Beyder, A. (2021) Mechanotransduction in gastrointestinal smooth muscle cells: role of mechanosensitive ion channels, Am J Physiol Gastrointest Liver Physiol 320, G897-G906.

[33] Nash, D. T., and Nash, S. D. (2008) Ranolazine for chronic stable angina, Lancet 372, 13351341.

[34] Neshatian, L., Strege, P. R., Rhee, P. L., Kraichely, R. E., Mazzone, A., Bernard, C. E., Cima, R. R., Larson, D. W., Dozois, E. J., Kline, C. F., Mohler, P. J., Beyder, A., and Farrugia, G. (2015) Ranolazine inhibits voltage-gated mechanosensitive sodium channels in human colon circular smooth muscle cells, Am J Physiol Gastrointest Liver Physiol 309, G506-512.

[35] Locke, G. R., 3rd, Ackerman, M. J., Zinsmeister, A. R., Thapa, P., and Farrugia, G. (2006) Gastrointestinal symptoms in families of patients with an SCN5A-encoded cardiac channelopathy: evidence of an intestinal channelopathy, Am J Gastroenterol 101, 12991304. 
Alteration of $\mathrm{Na}_{\mathrm{V}} 1.5$ mechanosensitivity by capsaicin

Cowan et al.

[36] Alper, S. L. (2017) Genetic Diseases of PIEZO1 and PIEZO2 Dysfunction, Curr Top Membr 79, 97-134.

[37] Zarychanski, R., Schulz, V. P., Houston, B. L., Maksimova, Y., Houston, D. S., Smith, B., Rinehart, J., and Gallagher, P. G. (2012) Mutations in the mechanotransduction protein PIEZO1 are associated with hereditary xerocytosis, Blood 120, 1908-1915.

[38] Bae, C., Gnanasambandam, R., Nicolai, C., Sachs, F., and Gottlieb, P. A. (2013) Xerocytosis is caused by mutations that alter the kinetics of the mechanosensitive channel PIEZO1, Proc Natl Acad Sci U S A 110, E1162-1168.

[39] Gonlachanvit, S., Mahayosnond, A., and Kullavanijaya, P. (2009) Effects of chili on postprandial gastrointestinal symptoms in diarrhoea predominant irritable bowel syndrome: evidence for capsaicin-sensitive visceral nociception hypersensitivity, Neurogastroenterol Motil 21, 23-32.

[40] Nikolaev, Y. A., Cox, C. D., Ridone, P., Rohde, P. R., Cordero-Morales, J. F., Vasquez, V., Laver, D. R., and Martinac, B. (2019) Mammalian TRP ion channels are insensitive to membrane stretch, J Cell Sci 132.

[41] Mazzone, A., Gibbons, S. J., Eisenman, S. T., Strege, P. R., Zheng, T., D'Amato, M., Ordog, T., Fernandez-Zapico, M. E., and Farrugia, G. (2019) Direct repression of anoctamin 1 (ANO1) gene transcription by Gli proteins, FASEB J 33, 6632-6642.

[42] Agarwal, M. K., Bhatia, S. J., Desai, S. A., Bhure, U., and Melgiri, S. (2002) Effect of red chillies on small bowel and colonic transit and rectal sensitivity in men with irritable bowel syndrome, Indian J. Gastroenterol. 21, 179-182.

[43] Aniwan, S., and Gonlachanvit, S. (2014) Effects of Chili Treatment on Gastrointestinal and Rectal Sensation in Diarrhea-predominant Irritable Bowel Syndrome: A Randomized, Double-blinded, Crossover Study, J. Neurogastroenterol. Motil. 20, 400-406.

[44] Patcharatrakul, T., and Gonlachanvit, S. (2016) Chili Peppers, Curcumins, and Prebiotics in Gastrointestinal Health and Disease, Curr Gastroenterol Rep 18, 19. 
Alteration of $\mathrm{Na}_{\mathrm{V}} 1.5$ mechanosensitivity by capsaicin

Page 25

Cowan et al.

\section{TABLES}

Table 1. Partition coefficients and $\mathrm{IC}_{50}$ values for amphipathic agents. Partition coefficients

497 peak whole cell $\mathrm{Na}^{+}$current from HEK293 cells transfected with Nav1.5.

\begin{tabular}{llll}
\hline & $\begin{array}{l}\text { Partition } \\
\text { coefficient } \\
\left(\log P_{\text {ow }}\right)\end{array}$ & $\begin{array}{l}\mathrm{IC}_{50} \\
(\mu \mathrm{M})\end{array}$ & Slope \\
\hline Amiodarone & 7.2 & 8.4 & 0.50 \\
Capsaicin & 3.04 & 60 & 0.64 \\
Propranolol & 3.48 & 7.6 & 1.01 \\
Triton X-100 & 4.6 & 5.3 & 1.00 \\
\hline
\end{tabular}

\section{Table 2. Effect of capsaicin on pressure-induced Nav1.5 mechanosensitivity in cell-attached}

patches. Effects of pressure $\left(0\right.$ or $-30 \mathrm{mmHg}$ ) on parameters of macroscopic $\mathrm{Na}^{+}$currents without

( $\left.\mathrm{I}_{\mathrm{MAX}}\right)$, voltage dependence of activation $\left(\mathrm{V}_{1 / 2 \mathrm{~A}}\right)$ or inactivation $\left(\mathrm{V}_{1 / 2 \mathrm{I}}\right)$, time constant of activation

$503\left(\tau_{\mathrm{A}}\right)$, time of inactivation recovery $\left(\mathrm{t}_{1 / 2 \mathrm{R}}\right)$, slope of inactivation recovery (slope), maximum use-

504 dependent inhibition (block), frequency of use-dependent inhibition $\left(f_{1 / 2}\right) . \mathrm{n}=8-24$ cells, ${ }^{*} P<0.05$,

5050 to $-30 \mathrm{mmHg}$ or $\uparrow P<0.05,0$ to $20 \mu \mathrm{M}$ capsaicin by a 2-way ANOVA with Tukey post-test.

\begin{tabular}{|c|c|c|c|c|c|c|c|c|}
\hline & $0 \mathrm{mmHg}$ & $\begin{array}{l}0 \mu \mathrm{M} \\
-30 \mathrm{mmHg}\end{array}$ & Change & $\mathbf{n}$ & $0 \mathrm{mmHg}$ & $\begin{array}{l}20 \mu \mathrm{M} \\
-30 \mathrm{mmHg}\end{array}$ & Change & $\mathbf{n}$ \\
\hline$I_{\operatorname{MAX}}(\%)$ & $100.0 \pm 0.0$ & $116.6 \pm 2.4^{*}$ & $16.6 \pm 2.4$ & 24 & $100.0 \pm 0.0$ & $104.8 \pm 3.0^{\dagger}$ & $4.8 \pm 3.0$ & 14 \\
\hline$V_{1 / 2 A}(m V)$ & $-41.9 \pm 3.0$ & $-46.4 \pm 3.0^{*}$ & $-4.5 \pm 0.6$ & 24 & $-57.5 \pm 2.8^{\dagger}$ & $-60.0 \pm 3.1^{\text {*† }}$ & $-2.4 \pm 0.6$ & 14 \\
\hline$V_{1 / 21}(m V)$ & $-54.1 \pm 3.1$ & $-60.1 \pm 3.3^{*}$ & $-6.0 \pm 0.9$ & 24 & $-70.5 \pm 3.3^{\dagger}$ & $-71.9 \pm 3.5^{\dagger}$ & $-1.4 \pm 1.2$ & 14 \\
\hline $\mathrm{T}_{\mathrm{A}}(\mathrm{ms})$ & $0.32 \pm 0.04$ & $0.26 \pm 0.04^{*}$ & $-20.0 \pm 5.3 \%$ & 24 & $0.23 \pm 0.04$ & $0.21 \pm 0.04$ & $-11.0 \pm 5.4 \%$ & 14 \\
\hline$t_{1 / 2 R}(m s)$ & $13.2 \pm 2.5$ & $22.1 \pm 4.9^{*}$ & $8.9 \pm 3.9$ & 11 & $29.5 \pm 6.4^{\dagger}$ & $48.7 \pm 9.4^{\star \dagger}$ & $19.2 \pm 8.6$ & 11 \\
\hline Slope $\left(\mathrm{ms}^{-1}\right)$ & $1.3 \pm 0.1$ & $1.2 \pm 0.1$ & $-0.10 \pm 0.17$ & 11 & $1.9 \pm 0.3$ & $2.3 \pm 0.8$ & $0.41 \pm 0.87$ & 11 \\
\hline Block (\%) & $80.9 \pm 7.9$ & $77.8 \pm 8.6$ & $3.2 \pm 9.4$ & 11 & $93.6 \pm 4.5$ & $85.5 \pm 8.5$ & $4.7 \pm 3.8$ & 8 \\
\hline$f_{1 / 2}(H z)$ & $22.3 \pm 2.6$ & $20.0 \pm 2.1$ & $-2.4 \pm 3.3$ & 11 & $19.1 \pm 2.5$ & $14.8 \pm 1.4^{*}$ & $-4.2 \pm 1.4$ & 8 \\
\hline
\end{tabular}


bioRxiv preprint doi: https://doi.org/10.1101/2021.07.13.452086; this version posted July 14,2021 . The copyright holder for this preprint (which was not certified by peer review) is the author/funder, who has granted bioRxiv a license to display the preprint in perpetuity. It is made available under aCC-BY-NC-ND 4.0 International license.

Alteration of $\mathrm{Na}_{\mathrm{v}} 1.5$ mechanosensitivity by capsaicin

Page 26 Cowan et al.

507 Table 3. Effect of capsaicin on shear-induced Nav1.5 mechanosensitivity whole cells. Effects

508 of shear stress $(0$ or $10 \mathrm{~mL} / \mathrm{min})$ on parameters of whole cell $\mathrm{Na}^{+}$currents without $(0 \mu \mathrm{M})$ or with

509 capsaicin $(20 \mu \mathrm{M})$ : maximum peak conductance (GMAX), maximum peak current density (IPEAK),

510 voltage dependence of activation $\left(\mathrm{V}_{1 / 2 \mathrm{~A}}\right)$ or inactivation $\left(\mathrm{V}_{1 / 2 \mathrm{I}}\right)$, time constants of activation $\left(\tau_{\mathrm{A}}\right)$

511 and fast $\left(\tau_{\mathrm{F}}\right)$ or slow inactivation $\left(\tau_{\mathrm{S}}\right)$, time of inactivation recovery $\left(\mathrm{t}_{1 / 2 \mathrm{R}}\right)$, slope of inactivation

512 recovery (slope), maximum use-dependent inhibition (block), frequency of use-dependent

513 inhibition $\left(f_{1 / 2}\right) . \mathrm{n}=8$-18 cells, $* P<0.05,0$ to $10 \mathrm{~mL} / \mathrm{min}$ or $\dagger P<0.05,0$ to $20 \mu \mathrm{M}$ capsaicin by a

514 2-way ANOVA with Tukey post-test.

\begin{tabular}{|c|c|c|c|c|c|c|c|c|}
\hline & $0 \mathrm{~mL} / \mathrm{min}$ & $\begin{array}{l}0 \mu \mathrm{M} \\
10 \mathrm{~mL} / \mathrm{min}\end{array}$ & Change & $\mathbf{n}$ & $0 \mathrm{~mL} / \mathrm{min}$ & $\begin{array}{l}20 \mu \mathrm{M} \\
10 \mathrm{~mL} / \mathrm{min}\end{array}$ & Change & $\mathrm{n}$ \\
\hline $\mathbf{G}_{\operatorname{MAX}}(\mathrm{nS})$ & $0.98 \pm 0.13$ & $1.24 \pm 0.22^{*}$ & $0.26 \pm 0.10$ & 12 & $0.78 \pm 0.12^{\dagger}$ & $0.85 \pm 0.15^{\dagger}$ & $0.08 \pm 0.05$ & 12 \\
\hline$I_{\text {PEAK }}(p A / p F)$ & $-66.8 \pm 12.3$ & $-86.6 \pm 17.7^{*}$ & $16.0 \pm 3.1 \%$ & 12 & $-56.7 \pm 58.5^{\dagger}$ & $-58.5 \pm 11.6^{\dagger}$ & $3.1 \pm 3.8 \%^{\dagger}$ & 12 \\
\hline $\mathrm{V}_{1 / 2 \mathrm{~A}}(\mathrm{mV})$ & $-57.3 \pm 1.7$ & $-58.9 \pm 1.4^{*}$ & $-1.5 \pm 0.6$ & 12 & $-58.9 \pm 1.5^{\dagger}$ & $-59.2 \pm 1.6$ & $-0.3 \pm 0.1$ & 12 \\
\hline $\mathrm{V}_{1 / 21}(\mathrm{mV})$ & $-90.3 \pm 3.3$ & $-92.7 \pm 2.6^{*}$ & $-2.5 \pm 0.9$ & 12 & $-95.4 \pm 2.6^{\dagger}$ & $-95.8 \pm 2.7^{\dagger}$ & $-0.5 \pm 0.6$ & 12 \\
\hline $\mathrm{T}_{\mathrm{A}}(\mathrm{ms})$ & $0.5 \pm 0.05$ & $0.39 \pm 0.02^{*}$ & $-20.4 \pm 3.3 \%$ & 12 & $0.39 \pm 0.04^{\dagger}$ & $0.38 \pm 0.04$ & $-1.3 \pm 7.0 \%^{\dagger}$ & 12 \\
\hline$T_{F}(m s)$ & $0.82 \pm 0.08$ & $0.57 \pm 0.04^{*}$ & $-27.5 \pm 4.0 \%$ & 12 & $0.80 \pm 0.08$ & $0.56 \pm 0.05^{*}$ & $-25.1 \pm 5.9 \%$ & 12 \\
\hline $\mathrm{T}_{\mathrm{s}}(\mathrm{ms})$ & $4.7 \pm 0.3$ & $3.5 \pm 0.2^{*}$ & $-24.2 \pm 4.4 \%$ & 12 & $3.8 \pm 0.3^{\dagger}$ & $2.9 \pm 0.2^{* \dagger}$ & $-20.5 \pm 4.8 \%$ & 12 \\
\hline$t_{1 / 2 R}(m s)$ & $18.8 \pm 1.7$ & $16.6 \pm 1.8^{*}$ & $-2.2 \pm 0.6$ & 8 & $38.0 \pm 4.5^{\dagger}$ & $28.4 \pm 4.2^{* \dagger}$ & $-9.5 \pm 0.9^{\dagger}$ & 8 \\
\hline slope $\left(\mathrm{ms}^{-1}\right)$ & $-1.26 \pm 0.04$ & $-1.28 \pm 0.05$ & $-0.02 \pm 0.02$ & 8 & $-1.43 \pm 0.02^{\dagger}$ & $-1.42 \pm 0.06$ & $0.01 \pm 0.04$ & 8 \\
\hline Block (\%) & $64.6 \pm 2.4$ & $64.7 \pm 2.6$ & $0.2 \pm 1.7$ & 18 & $89.0 \pm 1.4^{\dagger}$ & $83.9 \pm 2.0^{* \dagger}$ & $-5.1 \pm 0.9^{\dagger}$ & 10 \\
\hline$f_{1 / 2}(\mathrm{~Hz})$ & $26.1 \pm 2.0$ & $27.3 \pm 2.3$ & $1.2 \pm 0.9$ & 18 & $18.9 \pm 1.0^{\dagger}$ & $21.0 \pm 1.7$ & $2.1 \pm 1.4$ & 10 \\
\hline
\end{tabular}


Alteration of $\mathrm{Na}_{\mathrm{V}} 1.5$ mechanosensitivity by capsaicin

Page 27

Cowan et al.

\section{FIGURE LEGENDS}

\section{Figure 1. Amphipathic compounds inhibit voltage-gated $\mathrm{Na}^{+}$currents from $\mathrm{Nav} 1.5$ channels}

expressed in HEK293 cells. $A$, Molecular structures of the amphipaths (from left to right):

Figure 2. Capsaicin inhibits pressure- and shear-sensitivity of Nav1.5. $A$, Representative or $-120 \mathrm{mV}$ to $-30 \mathrm{mV}$ in a whole cell $(B)$, recorded at rest (filled symbols) or with force (empty symbols), in the presence of $0 \mu \mathrm{M}$ (black) or $20 \mu \mathrm{M}$ capsaicin (red). E-H, Maximum peak $\mathrm{Na}^{+}$ current $(E)$, time constant of activation $(F)$, and voltage dependence of activation $\left(G, \mathrm{~V}_{1 / 2 \mathrm{~A}}\right)$ or

536 inactivation $\left(H, \mathrm{~V}_{1 / 2 \mathrm{I}}\right)$, recorded with 0 or $-30 \mathrm{mmHg}$ pressure in the patch (left) and 0 or $10 \mathrm{~mL} / \mathrm{min}$ 537 shear stress in whole cells (right) in the presence of $0 \mu \mathrm{M}$ (black) or $20 \mu \mathrm{M}$ capsaicin $($ red $)$. $\mathrm{n}=$ 
Alteration of $\mathrm{Na}_{\vee} 1.5$ mechanosensitivity by capsaicin

Page 28

Cowan et al.

Figure 3. Effects of capsaicin on mechanosensitivity of Nav1.5 inactivation recovery time. $A$ -

$B$, Representative Nav1.5 currents at $-20 \mathrm{mV}$ in a cell-attached patch $(A, \bullet)$ or $-30 \mathrm{mV}$ in a whole

$\mathrm{mmHg}$ pressure; $B, 10 \mathrm{~mL} / \mathrm{min}$ shear stress) in the presence of $0 \mu \mathrm{M}$ (top) or $20 \mu \mathrm{M}$ capsaicin

Figure 4. Effects of capsaicin on mechanosensitivity of Nav1.5 use-dependent inactivation. $A$ -

$B$, Representative Nav1.5 currents at the $20^{\text {th }}$ pulse to $-20 \mathrm{mV}$ in a cell-attached patch $(A, \bullet)$ or to $-40 \mathrm{mV}$ in a whole cell $(B, \boldsymbol{\square})$, elicited at interpulse frequencies $3-33 \mathrm{~Hz}(A)$ or $3-50 \mathrm{~Hz}(B) . \mathrm{Na}^{+}$ $\mathrm{mL} / \mathrm{min}$ shear stress) in the presence of $0 \mu \mathrm{M}$ (top) or $20 \mu \mathrm{M}$ capsaicin (bottom). $C-D$, Use-

559 (black) or $20 \mu \mathrm{M}$ capsaicin (red), at $0(\bullet)$ or $-30 \mathrm{mmHg}$ pressure $(0)$ in the patch $(C)$ or at $0(\mathbf{\square})$ or $56010 \mathrm{~mL} / \mathrm{min}(\square)$ shear stress in whole cells $(D) . E-F$, Maximum use-dependent inhibition $(E)$ or

561 frequency of use-dependent inhibition $(F)$ versus pressure in the patch (left) and shear stress in whole cells (right) with $0 \mu \mathrm{M}$ (black) or $20 \mu \mathrm{M}$ capsaicin (red). $\mathrm{n}=8-18$ cells, $* P<0.05$ comparing 
bioRxiv preprint doi: https://doi.org/10.1101/2021.07.13.452086; this version posted July 14, 2021. The copyright holder for this preprint (which was not certified by peer review) is the author/funder, who has granted bioRxiv a license to display the preprint in perpetuity. It is made available under aCC-BY-NC-ND 4.0 International license.

Alteration of $\mathrm{Na}_{\mathrm{v}} 1.5$ mechanosensitivity by capsaicin

Page 29

Cowan et al.

5630 to $-30 \mathrm{mmHg}$ or 0 to $10 \mathrm{~mL} / \mathrm{min}, \uparrow P<0.05$ comparing 0 to $20 \mu \mathrm{M}$ capsaicin by a 2 -way ANOVA

564 with Tukey post-test.

565 
bioRxiv preprint doi: https://doi.org/10.1101/2021.07.13.452086; this version posted July 14, 2021. The copyright holder for this preprint (which

was not certified by peer review) is the author/funder, who has granted bioRxiv a license to display the preprint in perpetuity. It is made available under aCC-BY-NC-ND 4.0 International license.

Alteration of $\mathrm{Na}_{\mathrm{V}} 1.5$ mechanosensitivity by capsaicin

Page 30

Cowan et al.

566

FIGURES

\section{Figure 1.}

A

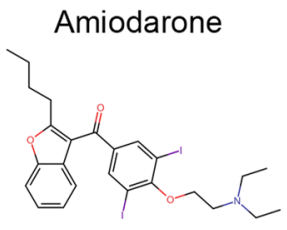

B

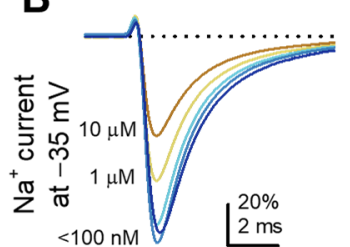

C Voltage $(\mathrm{mV})$

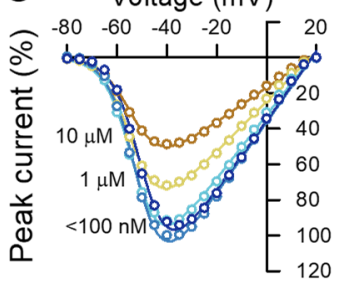

Capsaicin
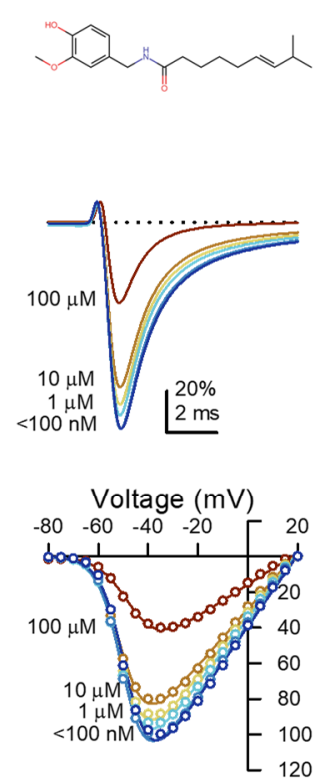

Propanolol
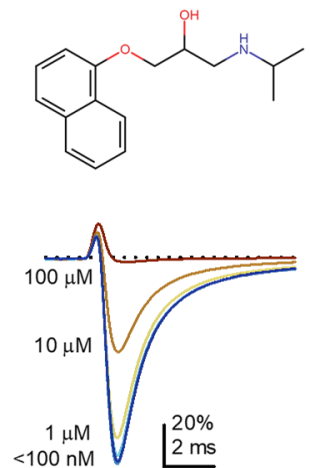

Voltage $(\mathrm{mV})$

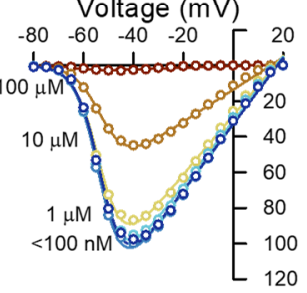

Triton X-100

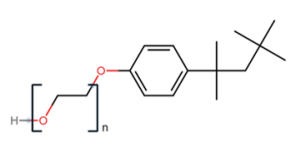

D
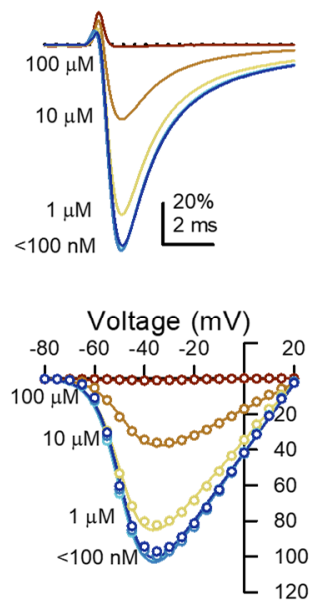

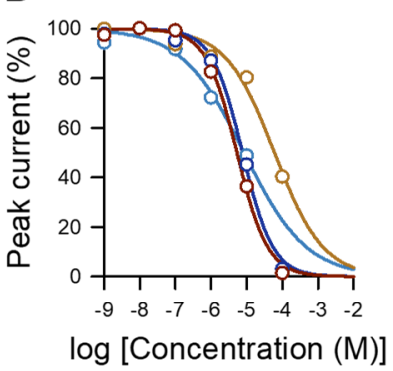


bioRxiv preprint doi: https://doi.org/10.1101/2021.07.13.452086; this version posted July 14,2021 . The copyright holder for this preprint (which was not certified by peer review) is the author/funder, who has granted bioRxiv a license to display the preprint in perpetuity. It is made available under aCC-BY-NC-ND 4.0 International license.

Alteration of $\mathrm{Na}_{\mathrm{V}} 1.5$ mechanosensitivity by capsaicin

Page 31

Cowan et al.

Figure 2.

A
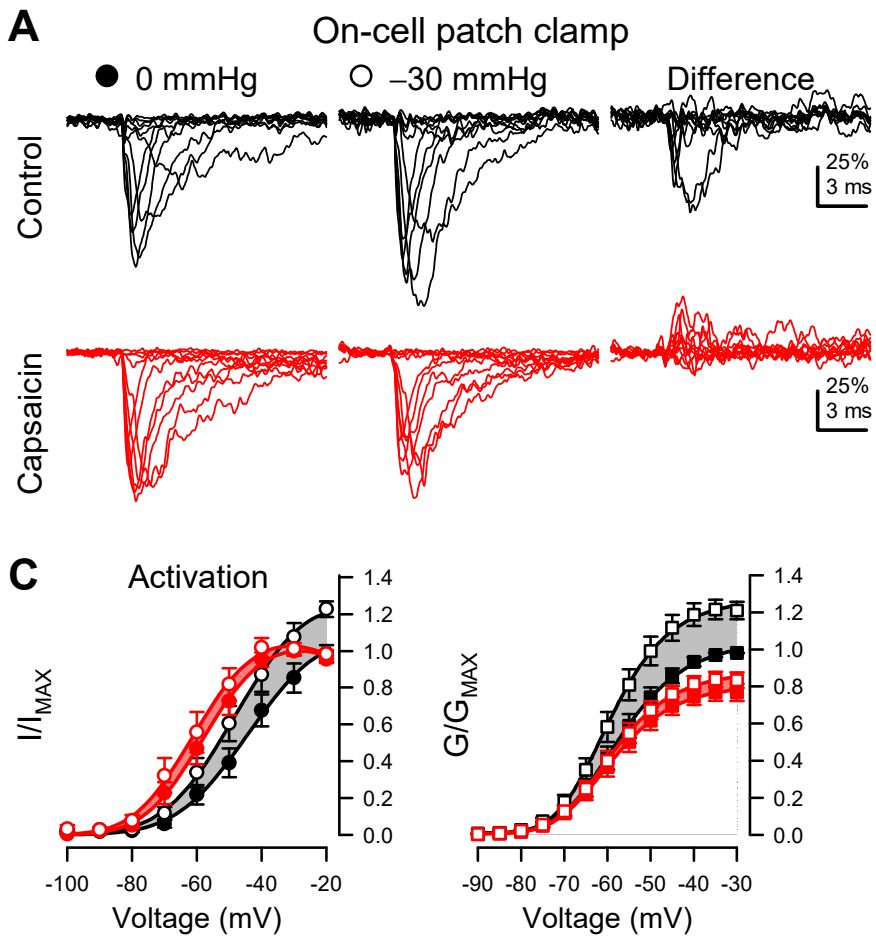

E Peak current

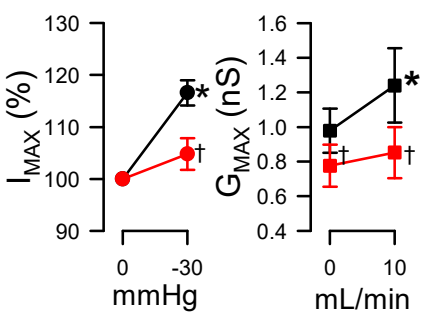

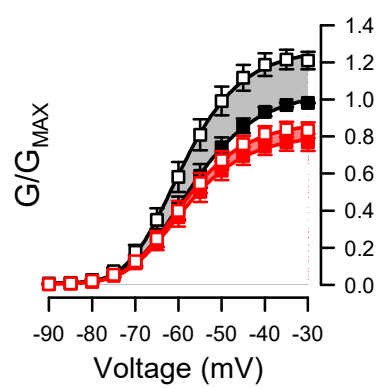

F Kinetics

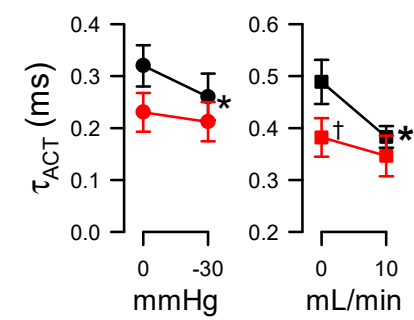

B Whole cell voltage clamp
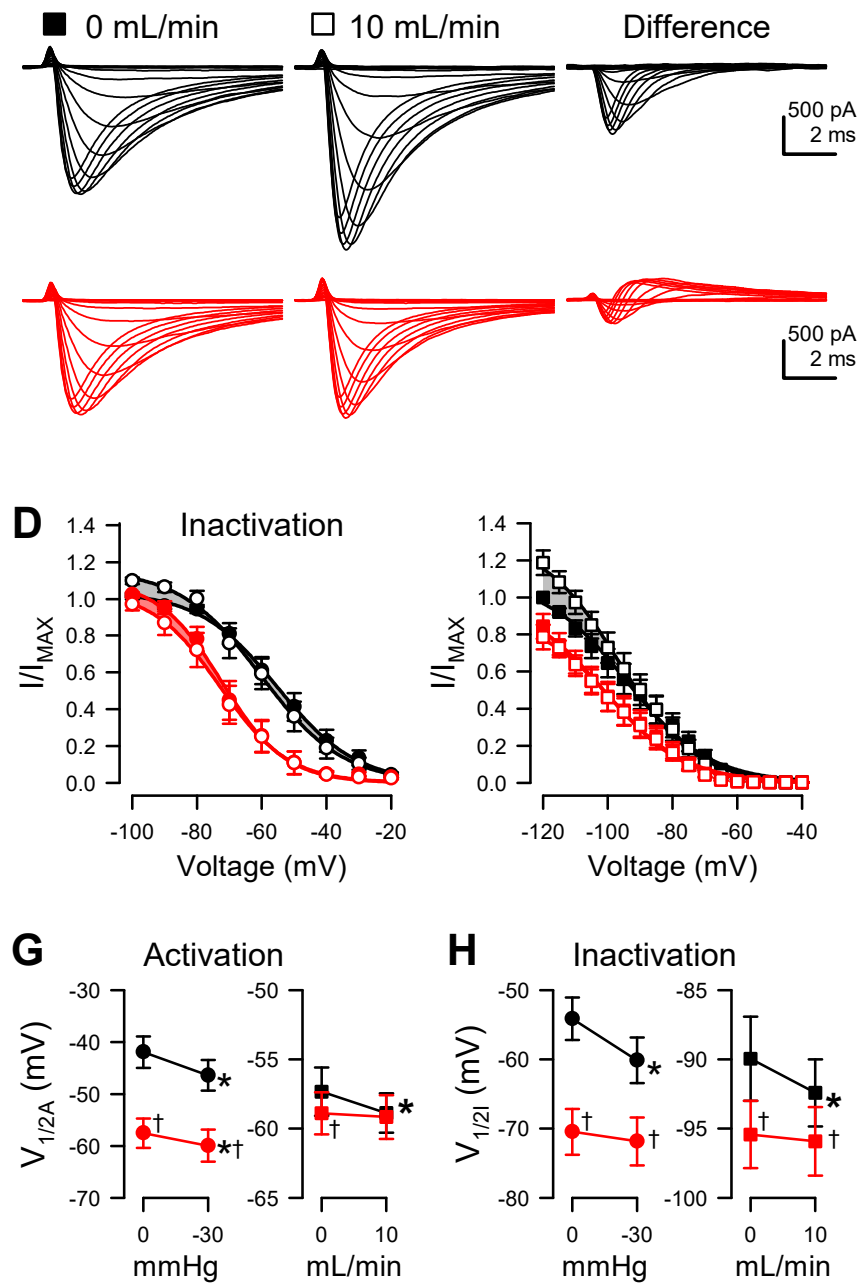
bioRxiv preprint doi: https://doi.org/10.1101/2021.07.13.452086; this version posted July 14,2021 . The copyright holder for this preprint (which was not certified by peer review) is the author/funder, who has granted bioRxiv a license to display the preprint in perpetuity. It is made available under aCC-BY-NC-ND 4.0 International license.

Alteration of $\mathrm{Na}_{\mathrm{V}} 1.5$ mechanosensitivity by capsaicin

Page 32 Cowan et al.

\section{Figure 3.}
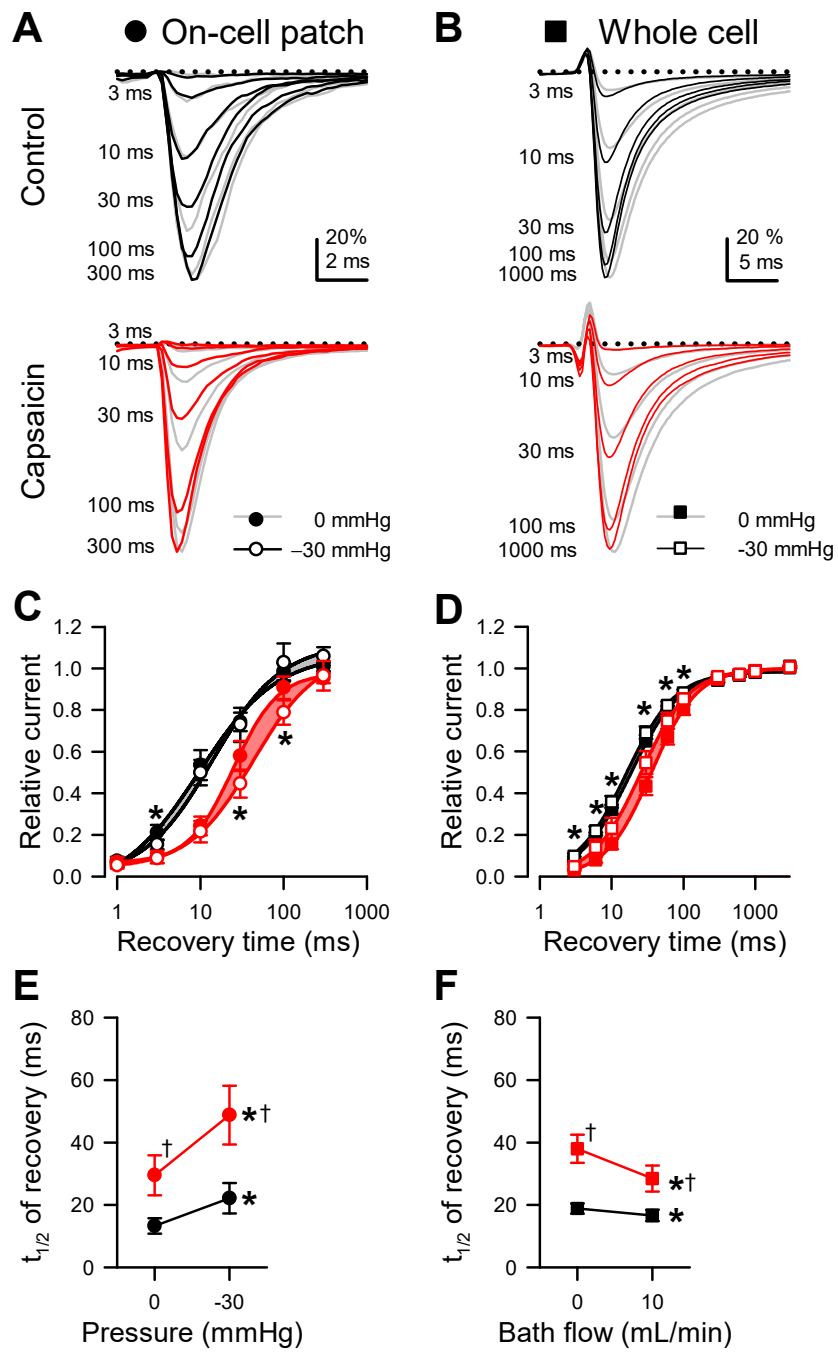
bioRxiv preprint doi: https://doi.org/10.1101/2021.07.13.452086; this version posted July 14, 2021. The copyright holder for this preprint (which was not certified by peer review) is the author/funder, who has granted bioRxiv a license to display the preprint in perpetuity. It is made available under aCC-BY-NC-ND 4.0 International license.

Alteration of $\mathrm{Na}_{\mathrm{V}} 1.5$ mechanosensitivity by capsaicin

Page 33 Cowan et al.

\section{$574 \quad$ Figure 4.}
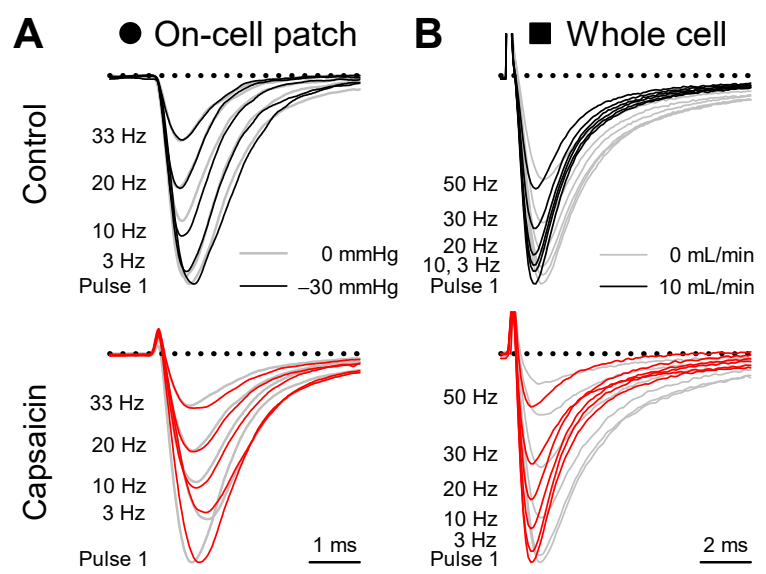

C

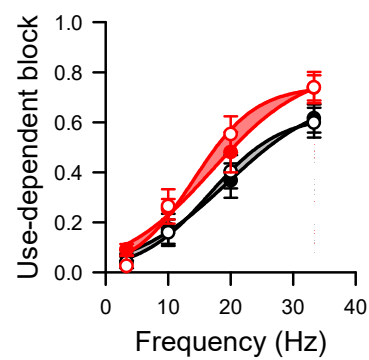

D
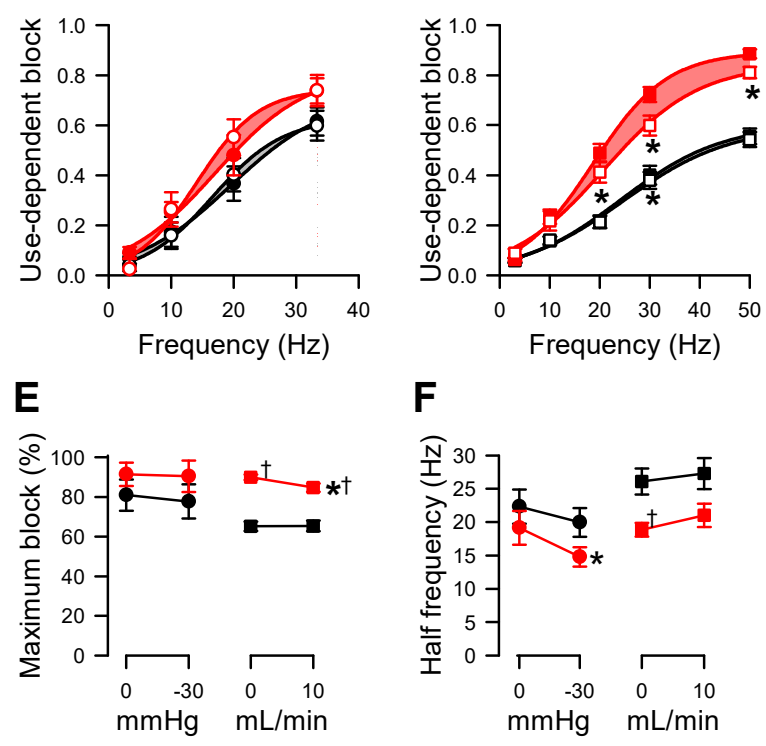